Creston Davis

\section{Organizing for Life}

Creston Davis is the founder and director of The Global Center for Advanced Studies (GCAS).

\section{Abstract}

In this article, I identify the need for intellectuals to organize around the core building blocks of life, air, water, and food. The article examines the lack of such organization on the left and the need to overcome the differences that fragment us. The article then goes on to propose a way of organizing in dialectical terms between protests, revolts on the one hand, and a "base" organized around a school committed to difference, discourse and conversation, and above all democracy.

"Responding to the challenges of capitalism in the world today must take the form of Organization \& Ideology" - Alain Badiou

Nearly weekly new reports emerge telling us about the growing disparities in our world. In nearly every instant these reports are as unbelievable as they are ominously true. Here is just one example: Oxfam recently reported that 85 of the richest people on the planet are as wealthy as the poorest half of the world. ${ }^{1}$

$1 \quad$ Graeme Wearden, “Oxfam: 85 richest people as wealthy as
And happily there was a response to this glaring social and economic inequality, which began on September 17, 2011 and spread throughout the globe. This became known as the "Occupy Movement." For a time, this movement looked very promising and has surely raised a level of consciousness about the central issue of justice. However, the long-term strategic effects of Occupy have faded away almost as quickly as it started. Although the Occupy movement has faded, the central issue of the injustice of extreme inequality not only remains with us but is growing with several detrimental effects. So the question I want to pose here is precisely how and under what means can we organize so that a sustained and long-term organization can be formulated without - and this is crucial - stifling the need to respond in the form of protest actions.

The seminal challenge before us thus can be posed in both positive and negative terms. It is positive, in that the very act of organizing is itself a response to this dangerous trend of the growing storm of injustice. For the alternative is unacceptable namely to idly stand-by

poorest half of the world," The Guardian, January 20, 2014, accessed September 18, 2014, http://www.theguardian.com/ business/2014/jan/20/oxfam-85-richest-people-half-of-theworld. 
doing nothing as more and more resources (the means of production) are being used to undermine the basic requirements for sustaining life: water, food, and shelter. Indeed, many scholars go so far to say that we have reached a moment in history where it is necessary to take a stance against this injustice otherwise we will continue to face increasingly more difficult times as even now laws have been enacted to undermine democratic action. ${ }^{2}$ In other words, everyone still has a choice to take a stance, and to fail to do so could mean that our world ineluctably will not be able to sustain life in just a generation or two.

The challenge is negative in that the means and resources for organizing (its premises, values, and practices) are gravely missing from our current common existential equation. A political philosopher and ethicist like Alasdair MacIntyre has conceded that there can't be any universal agreement about what constitutes "reasonable arguments," "[...] because," as Ted Clayton succinctly states, "we cannot agree on the premises of morality or what morality should aim at, we cannot agree about what counts as a reasoned argument, and since reasoned argument is impossible, all that remains for any individual is to attempt to manipulate other people's emotions and attitudes to get them to comply with one's own wishes." 3 And because a universal agreement in terms of rationality cannot be achieved, it requires MacIntyre, in a Wittensteinian gesture, to retreat from a dialogical common discourse into a "language game" symbolically organized within the conservative framework of intra-linguistically defined "tradition." Putting aside the basic critiques of MacIntyre's work, I agree with him on the point that to start a conversation
Internet Encyclopedia of Philosophy, accessed September 22, 2014, http://www.iep.utm.edu/p-macint/. (and action) requires some minimal level of agreement. This raises the question: Is there some form of common agreement we can come to in terms of a foundation, an organization on the bases of which sustained action and intellectual work is possible? Said differently, given the fact that the capitalistic regime of greed is waging a war against the reality of life as such, it is necessary to establish a common front that will protect humanity against this war on life. I believe such a front can and must be organized and there are conceptual and practical resources available for the purposes of constructing this vantage point; a vantage point of life.

Risking the inevitable critique of extremely privileged intellectuals (even and especially the ones who claim to be liberal progressives and there are a lot more than you think), I would like to propose that we can all agree that for life to continue each person, village, city, region and our very planet needs clean (i.e., non-toxic) air and water. Air and water, it's really very simple. To breathe air is essential, but not just air, clean air is essential for health. Clean water too is essential for life, and it is needed every day. Air every moment, and water every day are the essential building blocks of life and health, of all things, social, economic, political, cultural. So, as reductive and basic as it may seem, we must first start with the foundations of life and build from here a way of framing existence, such that a healthy life is not only possible but also sustainable over time and for all people.

But to understand our world in the simplest of terms remains the issue that very few academics are able to focus on. The reasoning for this may touch on how incestuous and neoliberal the academy has become on the level of individual scholarship. New languages and complex symbolic structures are constructed precisely to become increasingly exclusive with each new book or 
article. Complex and esoteric language systems, much like the original medieval castles, keep academics from confronting the very building blocks of our common life together. And the so-called, "public intellectuals" too often fold to sensational topics in order to sell books to continue making a living. But there are exceptions. For example, Naomi Klein's recent book, This Changes Everything: Capitalism vs. the Climate refreshingly and quite literally comes down to earth: Earth, Water, Air. Klein's ability to articulate this is extraordinary, as the recent interview with John Tarleton makes clear. Klein bucks the moralism of personal ethics. She decisively frames the approach by saying it's not about your personal habits of recycling, but rather about the systemic way in which citizens are unable to stop corporations from destroying the environment around their towns. Think of the recent and dangerous trend of hydraulic fracturing or "fracking" "which has systematically contaminated the vital water sources of local towns throughout the United States. Klein's approach is much like Slavoj Žižiek's use of Lenin's distinction between formal and actual freedom. Formal freedom is the freedom to choose from an already predetermined set of options, like choosing food in a buffet. By contrast, actual freedom is the ability to choose to reject formal freedom, i.e., the buffet itself. So, what Klein is saying is that one's personal choices to recycle, buy a Prius and so on, lines up with Lenin's idea of formal freedom. What Klein is trying to get us to think, however, functions on the level of actual freedom.

$4 \quad$ Fracking is defined as "the process of drilling and injecting fluid into the ground at a high pressure in order to fracture shale rocks to release natural gas inside.” The problem with fracking is that nearby water sources are vulnerable to contamination by the toxins used in the process such as lead, Radium, Methanol, Uranium, Mercury, Ethylene Glycol. http://www. dangersoffracking.com (accessed January 3, 2015).
But here is where the challenge emerges: A public intellectual must lucidly communicate complex concepts easily enough for most people to grasp. So when she tries to communicate to us (the public) about the need to direct our energies to challenging the capitalist corporate system, most citizens find this extreme and even alienating. Challenging the "system" is alienating to the citizen for two reasons: first, because the citizen is so imbricated into the logic of capitalism that for them to challenge it requires them to sacrifice their own way of life. Think about it, citizens in capitalist societies have to pay for mortgages, debts, bills, car payments, gym memberships, cell phone bills and so on just to keep functioning and to stay afloat. And in doing this, citizens continue to reproduce the very system Klein is asking us to challenge. So, naturally, someone reading Klein's argument might like it, but have no resources to enact it, thus leaving a gap between abstract ideas and concrete action. So strangely, what then is required is either we figure out a way to stop capitalism or else before long, the planet will no longer sustain life. But, to do this requires each individual imbued in the logic of capital to radically alter his or her life-styles, but to do so without causing unnecessary harm. Avoiding harm shouldn't be equated to the conservative stance of doing nothing or even not taking risks. Risks will be necessary to change the system on which much of our life depends. Said differently, we must change our lives soon and very soon or else the future generations of our planet won't have a chance to breathe.

Academics can continue filling up their studies in peerreviewed journals all they want, proving facts about the dangers of radical climate change, but unless this message is able to be clearly and coherently communicated to citizens we'll remain pathologically on the same slide into oblivion. The key here, thus, is communication and 
organization. Communication in that the facts needs to be delivered clearly and accurately. But that still isn't enough-action is required. Organization needs to take place on both the local and global level. Organization that has to do with the basic questions of life: water, air, shelter.

The trends of today's capitalist world, the so-called "free market" world does not take into account a standard of health for all people, that is to say, for the planet. The universal for capitalism is profit at the cost of all else, including human beings, the planet and all manner of life. In this sense, capitalism is soullessly pathological because it sacrifices life for material gain for an increasingly smaller demographic. The outcome of capitalist gain is then re-invested for further gain and this logic of accumulation madness is obsessive as it is compulsive. Objectively we can observe this mad logic by the numbers in the surveys in which wealth is increasingly concentrated into the control of fewer and fewer people. Thus, a aristocracy is emerging on the bases of which a new foundation that Philip Goodchild calls a "Theology of Money" has already been erected. And here we must revive what MacIntyre says that we are in a new "dark ages." We are not so much in a new dark age as we are in feudalism in which the church has been supplanted by Wall Street and the capitalist has become the aristocracy of our time. . This axis, something that has been forming from the early $70 \mathrm{os}$, is nothing less than a threat to life as such and we must organize to stop it. But, again, to do this will require great sacrifices and turns on the question: Are the middle and working classes willing (as they are certainly able) to give up the capitalist fantasy otherwise known as the "American Dream" in order to save the future generation from extinction. This should be our task and our mission must begin with the basics of life, water, food, and added to this, shelter.

\section{Organization, Action \& Protest}

In light of this new elitism that is now controlling the capitalist world, we have witnessed reactions and protests in recent years. The two main protests have been the "Arab Spring" and the "Occupy Movement." And much good has resulted from these movements, and in the case of the former, much danger has emerged. But, in regards to the latter, no serious social change has come to realization. What then can be done?

Let's begin by assessing the weaknesses of the Occupy movement. There are internal and external weaknesses. The internal one has to do with the liberal politics that infiltrated the movement and turned its radical edge into a conservative stance that finally pandered to the status quo. Instead of occupying public spaces as an act of defiance to the point of breaking the law, the movement decided to cater to the demands of the state. . At the end of the day, only a few and not the common risked standing together against the state. In other words, at the end of the day, the liberal stance of "We'll protest so long as the law maintains its authority" only concedes the law, having precedence over the injustice of the state's axis to the death politics of the wealthy. The point being: the unjust politics of Wall Street continues to function as the state of exception whereas the multitude must be tamed by the law-the very logic that allows the wealthy to continue operating unjustly without accountability by the people.

This is also why liberal politics (that which undergirds and supports the university profit-making system) are impotent. Universities, within the neo-liberal

5 During the Fall, 2014 we have seen more protests and uprisings surrounding the murder of Michael Brown in Ferguson, which certainly are gaining more and more strength globally. 
regime, can only ever reproduce the stalemate of the capitalist culture because although they have a few socalled "radical thinkers" they are often but not entirely rendered powerless by the golden handcuffs of tenure. The psychological fears the college professor experiences are so palpable it too frequently shocks them into a researcher that can only ever complain about identity politics while sipping on gins-and-tonics. This fear must be broken with the courage to speak the truth about our life on this planet, and it cannot be done by just talking about how bad everything is from the forests evaporating to the massive ice melts. These are but symptoms of a much greater and ominous systematic attack by the capitalist regime against our planet. Courage must be conjured, and a call to action must be sounded. This is war, but a war that must be waged on principles of justice and a politics of life and love. But it is also a war whose veneer-fantasy called the "middle-class" cannot see behind their closed doors, fancy cars, in what is already a pathological repression otherwise known as zombie politics.

The external problem with the Occupy movement has to do with sustainability. More strictly, the problem is organizational sustainability. The protest nature of Occupy was unable to sustain itself over a long period of time. If, however, there was an institution established that can sustain itself through long-term organizing and community program development, while at the same time being able to respond to injustice through needed protest then the overall demand for justice by the people can be sustained. The pressure for change, for justice must be unrelenting through a dual strategy of short and long-term action plans. Additionally, this dual strategy will work to help keep the long-term institution from falling asleep and sinking back into apathy and the status quo through protest action, and conversely, the protest action will be grounded in a sustainable vision so that it doesn't just become a flash-in-the-pan and quickly evaporate leaving no long-term outcome.

\section{Organizational Form}

This raises the question: What "institutional" form should this organization take? There are many options: community organization, a global political party, an organization shaped around a specific issue (women's rights, etc.) and so forth. There are many great strengths to organizing locally, but the biggest weakness is that it isn't connected to the plight of the oppressed around the globe and so whatever changes they bring to the local domains, as good as they are, must also be linked to the global fight for justice. It was Martin Luther King, Jr. who once said "Injustice anywhere is a threat to justice everywhere.” And given the advanced technologies we have today at our disposal, we must take advantage of them in order to form a global/local institution so that our struggle for justice and democracy can have both the local and the global connected together into a network of communication and action for the voice of the common. Thus the question becomes: What institutional form would serve these purposes best: (a) sustainability; (b) protest action; (c) local; and (d) global? My proposal is the formation of a school grounded in the pursuit of justice by the perpetual desire to raise consciousness and organize solidarity around justice as well as be able to deploy action to confront injustice in a way that is both sustainable and yet ever unfolding through itself. This action, moreover, must be motivated at all times towards a politics of life and inclusion.

I, along with many comrades, including Katerina Kolozova, have started a school with this strategy in mind. The school is called The Global Center for Advanced 
Studies (GCAS). Alain Badiou is the president of this school and it contains leading theorists and activists on the faculty. The great strength of this school, as our President states, is that "It is neither reducible to a party, nor is it strictly an intellectual endeavour." A school like GCAS can thus unite the oppressed on a global front while deploying local action in the name of democracy and emancipation. Seminar courses can be taught in a way that raises the level of consciousness globally, while also organizing action locally. What is more, because it is a school it must not take up dogmatic positions, but must rather, as Max Horkheimer pointed out in his important book Traditional and Critical Theory (1937), become a self-conscious social critique with the mission for emancipation through enlightenment, which does not cling dogmatically to its own foundational assumptions. ${ }^{6}$ Closely related to this is Michael Hardt and Antonio Negri's idea of the "multitude" in which they say,

“...there must be a moment when reappropriation and self-organization reach a threshold and configure a real event. This is when the political is really affirmedwhen the genesis is complete and self-valorization, the cooperative convergence of subjects, and the proletarian management of production become a constituent power."

With Horkheimer's call to not dogmatically cling to doctrinal assumptions, but yet continue the process of enlightenment, together with Badiou's idea of the

6 Raymond Geuss, The Idea of a Critical Theory: Habermas and the Frankfurt School (Cambridge University Press, 1981. Page 58). Retrieved from The Frankfurt School Wikipedia entry, accessed September 18, 2014, https://en.wikipedia.org/wiki/ Frankfurt_School.

7 Michael Hardt \& Antonio Negri, Empire (Cambridge: Harvard University Press, 2000. Page 411).
Event and with Hardt and Negri's notion of the coming multitude that hasn't yet actualized itself, we have a model for a school that can function as a global/local organization, which allows for an infinite diversity, whilst at the same time, a specific sustainable strategy both strategic and tactical (short and long term, global and local).

With this very anemic strategic model in place (which is in great need of being fleshed out), we can start with the school itself as we begin the formation of global and local organizations, and through this school, we can then build a communication network that contains within it the ability to ignite actions and knowledge about the spreading injustices around the world issuing from global capitalism and neoliberalism waging war against the essential elements of life. GCAS and other schools must then be committed to life above all, to health and be a movement not only of resistance and protest, but also of producing a positive unfolding of life.. And finally, such a school is just one proposal among many that already exist and have for some time now. But uniting these different organizations committed to life can form a global community that could, if organized carefully, begin to assist us as we fight and struggle for life, for breath, air, water and shelter for all. 